\title{
DETERMINANTY SKUTECZNEJ KOMUNIKACJI W MODELU BIZNESOWYM B2C
}

\author{
Roksana Włodarczyk \\ Politechnika Częstochowska \\ Wydział Zarządzania
}

\begin{abstract}
Streszczenie: Współczesna działalność handlowa upowszechnia się w Internecie. Przedsiębiorstwa, które chcą rozwijać swoją działalność handlową na rynku krajowym, jak i zagranicznym, powinny podążać za nowymi rozwiązaniami informacyjno-komunikacyjnymi i odpowiednio je dostosować do specyfiki swojej branży. Przybiera zatem na znaczeniu wypracowanie modelu skutecznej komunikacji zarówno wewnątrz przedsiębiorstwa, jak i z jego otoczeniem. Celem niniejszego artykułu jest określenie determinantów skutecznej komunikacji przedsiębiorstwa $\mathrm{z}$ klientami. Ponadto wskazano najbardziej efektywne kanały komunikacji. W celu ustalenia hierarchii ważności determinantów sprawnej komunikacji przeprowadzono badanie ankietowe $\mathrm{w}$ wybranych firmach $\mathrm{z}$ branży meblowej.

Słowa kluczowe: komunikacja elektroniczna w przedsiębiorstwie, zasady skutecznej komunikacji, elektroniczne narzędzia komunikacji, skuteczność internetowych kanałów komunikacji, komunikacja z klientem, model biznesowy B2C
\end{abstract}

DOI: 10.17512/znpcz.2016.2.24

\section{Wprowadzenie}

Dynamiczny rozwój Internetu oraz jego powszechne zastosowanie w celach lukratywnych, internacjonalizacja, konkurencja pomiędzy firmami z tej samej branży oraz rosnące wymagania konsumentów są czynnikami, które przyczyniają się do rozwoju sektora firm internetowych (Nowak 2011, s. 143-150). Elektroniczna forma prowadzenia działalności gospodarczej jest określana mianem gospodarki elektronicznej, handlu elektronicznego (ang. electronic commerce), biznesu elektronicznego (ang. electronic business), biznesu kolektywnego (ang. collective business), cyfrowej gospodarki (ang. digital economy), cyberekonomii, nowej gospodarki, gospodarki opartej na wiedzy (ang. knowlegde-based economy), gospodarki internetowej lub gospodarki sieciowej (ang. network economy) (Niedźwiedziński 2004, s. 7). Bez względu na stosowany termin, gospodarka elektroniczna jest to „elektroniczna platforma prowadzenia działalności gospodarczej, na której dochodzi do kontaktów pomiędzy uczestnikami procesów gospodarczych, dokonywane są transakcje, następuje tworzenie i wymiana wartości" (Niedźwiedziński 2004, s. 7). Definicja pojęcia „przedsiębiorstwo” jest trudna do uściślenia, ponieważ przybiera różnorodne formy, w zależności od przyjętego modelu biznesowego. R. Amit i C. Zott formułują model biznesu jako „[...] substancję, strukturę oraz system nadzoru transakcji zaprojektowany w celu kreowania wartości poprzez eksploatację szans biznesowych" (Amit, Zott 2001, s. 511). 
Podstawowe modele e-biznesu to: B2B (ang. bussiness-to-bussiness) oraz B2C (ang. bussiness-to-customer). Pierwszy z nich określa relację między przedsiębiorstwami, drugi model dotyczy relacji między przedsiębiorstwami a konsumentami (Niedźwiedziński 2004, s. 130). Jednakże eskalacja zastosowania Internetu doprowadziła do powstania kolejnych modeli:

- C2C (ang. customer-to-customer) - stronami są klienci zawierający między sobą transakcje bez udziału firm (np. aukcje elektroniczne).

- C2B (ang. customer-to-business) - stroną inicjującą jest klient w stosunku do przedsiębiorstwa (np. zakupy przez Internet) (Ordysiński 2007, s. 16).

- C2A (ang. customer-to-administration) - w przypadku relacji między konsumentami a administracją publiczną.

- B2A (ang. business-to-administration) - w przypadku relacji między przedsiębiorstwami a urzędami (Niedźwiedziński 2004, s. 130).

$\mathrm{Z}$ perspektywy przedsiębiorców prowadzących małe i średnie firmy najistotniejsze znaczenie mają modele B2C oraz B2B. Generalnie przedsiębiorstwa są ukierunkowane na cyfryzację wybranych lub wszystkich działań i procesów biznesowych (Hull i in. 2007, s. 290-303). Internet i wirtualne otoczenie nadają nowatorskie znaczenie relacjom przedsiębiorstwa $\mathrm{z}$ klientami poprzez wielostronną komunikację, szeroki dostęp do informacji, zawieranie transakcji, kreowanie innowacji czy współtworzenie wartości (Jelonek 2014b, s. 20). Przedsiębiorstwa wykorzystują Internet do skutecznego komunikowania się ze swoimi obecnymi i potencjalnymi klientami w celu zwiększenia sprzedaży, efektywnej poprawy jakości relacji z klientami, przy jednoczesnym obniżeniu kosztów globalnej dystrybucji. Skuteczna komunikacja to podstawa dobrego zarządzania każdego przedsiębiorstwa. Ukazuje ona poziom, w jakim działania komunikacyjne wpłynęły na uzyskane wyniki (Nowak 2001, s. 143-150). Zatem jest istotnym elementem wszystkich podejmowanych działań, ponieważ jej niska skuteczność wpływa negatywnie na efektywność całego przedsiębiorstwa.

\section{Charakterystyka modelu biznesowego B2C}

Handel elektroniczny typu B2C obejmuje usługi finansowe (np. bankowość elektroniczna, ubezpieczenia, fundusze inwestycyjne), usługi niefinansowe (turystyczne, obrót nieruchomościami itd.) oraz sklepy internetowe (m.in. Amazon.com czy polski E-market), których oferta skierowana jest do klientów indywidualnych. Ten model gwarantuje przedsiębiorstwu liczniejszą rzeszę klientów, możliwość zapoznania się z ich preferencjami, obniżenie kosztów świadczonych usług oraz możliwość zakupu przez 24 godziny 7 dni w tygodniu (Ordysiński 2007, s. 16). $\mathrm{Z}$ perspektywy struktury oferowanych produktów wyodrębnia się sklepy internetowe horyzontalne i wertykalne. Pierwsze $\mathrm{z}$ nich oferują obszerny wachlarz wyrobów z wielu branż, zaś sklepy wertykalne są zorientowane na sprzedaż z określonej branży (Niedźwiedziński 2004, s. 131). Zasadnicze pobudki, dla których klienci korzystają z handlu elektronicznego, to (Januła, Truś 2010, s. 99): 
- wygoda,

- dostęp do informacji,

- duży wybór produktów,

- duża liczba sklepów,

- niskie ceny,

- indywidualizacja oferty.

Handel elektroniczny B2C odszedł od obowiązującego wzorca gospodarki tradycyjnej na rzecz systemów dynamicznych (Januła, Truś 2010, s. 100).

\section{Wybrane kanały komunikacji z klientem w e-przedsiębiorstwie}

Pojawienie się handlu internetowego rewolucjonizuje organizację pracy w przedsiębiorstwach. Współcześnie Internet jest wykorzystywany jako narzędzie komunikacji przedsiębiorstwa z klientami. Coraz częściej przedsiębiorstwa oferują klientom różnorodne formy kontaktu, ponieważ użytkownicy Internetu nie należą do tożsamego grona pod względem upodobań korzystania $\mathrm{z}$ oferowanych kanałów komunikacyjnych. Klient indywidualnie podejmuje decyzję, czy proponowana forma komunikowania się z przedsiębiorstwem jest dla niego wygodna, praktyczna i czy z niej skorzysta (Jelonek 2014a, s. 322). Klienci z każdej grupy wiekowej korzystają z jakiegoś kanału komunikacji zintegrowanej, dlatego też oczekują wielokanałowości od przedsiębiorstw (Genesys 2010, s. 3). Dostępne formy komunikacji za pośrednictwem sieci komputerowych klasyfikuje się na jednostronne i interaktywne. Jednostronna komunikacja cechuje się tym, że nadawca nie zwraca się bezpośrednio do określonego odbiorcy i nie oczekuje odpowiedzi. Do jednostronnych form komunikacji należą: strony WWW, baza danych, prasa elektroniczna. Natomiast komunikacja interaktywna wymaga udziału co najmniej dwóch osób wchodzących w interakcję. W obrębie komunikacji interaktywnej można wyróżnić formy synchroniczne (osoby porozumiewające się odbywają rozmowę w czasie rzeczywistym) oraz asynchroniczne (reakcje odbiorcy są odroczone w czasie, co wpływa na sposób porozumiewania się, ponieważ pozwala odbiorcy na przemyślenie odpowiedzi). Do komunikacji synchronicznej zaliczamy: czat, IRC, komunikatory internetowe, np. Gadu-Gadu czy Skype. Z kolei wśród asynchronicznych form możemy wyróżnić m.in. listy dyskusyjne, grupy dyskusyjne (Janas 2012, s. 201), pocztę elektroniczną. Niemniej e-mail pozostaje jednym z najpopularniejszych sposobów pierwszego kontaktu zainteresowanych odbiorców (Morawczyński 2008, s. 74). Pozostałe, równie powszechnie znane i wykorzystywane środki komunikacji klienta $\mathrm{z}$ firmą to między innymi: formularze na stronie internetowej, blog na portalu firmowym, rozmowa wideo. Aktualnie coraz większe uznanie zyskują portale społecznościowe oraz platformy współpracy z klientem w zakresie innowacji. Przedsiębiorstwa wykorzystują media społecznościowe jako narzędzie do pozyskiwania nowych i utrzymania obecnych klientów oraz do zachęcania ich do dzielenia się propozycjami i pomysłami, jak i angażują klientów do prac nad tworzeniem i rozwojem produktów i usług (Jelonek 2014a, s. 322). 


\section{Bariery w skutecznym komunikowaniu się z klientem}

Komunikacja elektroniczna powinna być procesem skutecznym, czyli prowadzącym do jak najlepszego zrozumienia nadawanego komunikatu. Jednakże nadawca i odbiorca mogą popełnić błędy (Ober 2007, s. 23) i wówczas powstają tzw. bariery komunikacyjne. Poznanie natury barier umożliwia ich redukcję, co też uskutecznia proces komunikacji, usprawnia pracę oraz relacje interpersonalne. Do przeszkód skutecznej komunikacji elektronicznej należą (Ober 2007, s. 24):

1. Różnice w postrzeganiu - są wynikiem indywidualnej percepcji. W zależności od posiadanej wiedzy i doświadczenia ta sama informacja może być odmiennie zrozumiana przez różnych ludzi.

2. Emocje - wpływają na zrozumienie komunikatów i na to, w jaki sposób nasza informacja zostanie odebrana przez innych.

3. Nieufność - jest istotnym elementem w komunikacji, ponieważ zaufanie nadawcy do jego wiedzy i doświadczenia w sprawie treści komunikatu oraz dobre relacje przyczyniają się do skuteczniejszej współpracy.

4. Bariery społeczne - polegają na istnieniu społecznej stratyfikacji swoistego „punktu widzenia” określonych grup, który w sposób obiektywny dokonuje „przesunięcia semantycznego".

5. Różnice językowe - mają zasadniczy wpływ na zrozumienie przekazywanego komunikatu, ponieważ język jest strukturą wielopiętrową, składającą się z wielości znaczeń (Morawczyński 2008, s. 65), i aby informacja została zrozumiana, musi znaczyć to samo dla nadawcy i odbiorcy (Ober 2007, s. 24).

6. Różnice kulturowe - odgrywają podstawową rolę w procesie komunikowania się z klientami, ponieważ wpływają one na zachowania nabywcze. Nieznajomość kultury, obyczajów, tradycji naszego partnera komunikacji wpływa negatywnie na proces porozumiewania się.

Do wyżej wymienionych błędów komunikacyjnych w modelu B2C należy również uwzględnić klasyfikację M. Holstein-Beck (Holstein-Beck 2001, s. 64):

1. pominięcie - polega na nieprzetworzeniu części informacji,

2. błędy w piśmiennictwie - czyli nieadekwatne przetworzenie komunikatu,

3. magazynowanie - czyli opóźnianie przetworzonego komunikatu,

4. przybliżanie - czyli zacieranie różnic występujących w treści komunikatu,

5. ucieczka - czyli zaprzeczanie nadawania i odbierania komunikatów.

Każdy z wyszczególnionych elementów ma istotny wpływ na skuteczną komunikację przedsiębiorstwa $\mathrm{z}$ klientem. Przedsiębiorcy powinni pamiętać, że kontakt z klientem to nie tylko komunikacja przed sprzedażą, ale również po niej, dlatego też należy minimalizować błędy w komunikacji. Ponadto, aby komunikacja z klientem była skuteczna, należy stosować zasady skutecznej komunikacji (Guide de Gestion des Ressources Humaines, s. 5):

1. Zasada skupienia - należy rozpoznać potrzeby klienta i odłożyć te, które nie są dla niego przydatne w danej chwili; zasada ta pozwala skupić się na najistotniejszych celach oraz umożliwiać zachowanie jasności umysłu w trudnych sytuacjach). 
2. Zasada dystansowania - należy zachować „dystans emocjonalny” w relacjach interpersonalnych, dzięki tej zasadzie łatwiej jest się wycofać z komunikacji, pozwala zachować pewną neutralność w problematycznych sytuacjach.

3. Zasada przejrzystości - należy jasno wyrażać swoje zamiary oraz jasno określić obszar działania, ponieważ zasada ta pozwala wyeliminować wrażenie bycia manipulowanym oraz daje możliwość nawiązania i utrzymania więzi zaufania.

4. Zasada spójności - należy przyjąć zachowania i postawy, które są zgodne z zamiarami, czyli „robisz to, co mówisz”, i tym samym tworzyć wiarygodne wiadomości.

5. Zasada wzajemności - podtrzymywanie relacji interpersonalnych, pozwala rozpowszechniać informacje w obu kierunkach oraz stworzyć obieg informacji.

6. Zasada szacunku - należy spostrzegać osobę nie tylko jako pracownika, ale jako człowieka.

Stosowanie wymienionych zasad przez przedsiębiorcę oraz klienta pozwala usprawnić komunikację oraz przyczynia się do lepszego funkcjonowania firmy.

\section{Procedura badawcza}

W celu ustalenia czynników warunkujących skuteczną komunikację w przedsiębiorstwie przeprowadzono badanie $\mathrm{z}$ udziałem przedsiębiorstw z branży meblowej prowadzących działalność handlową w Internecie. Prezentowane wyniki pochodzą z kwietnia 2016 r. Badania zostały przeprowadzone metodą sondażu diagnostycznego, zaś techniką zbierania danych była ankieta. Za narzędzie badawcze posłużył kwestionariusz ankiety wysłany drogą e-mailową do 200 wybranych losowo przedsiębiorstw prowadzących sprzedaż internetową w całej Polsce. Do analizy zakwalifikowano 144 przedsiębiorstwa, ponieważ zawierały pełen zestaw wymaganych informacji. Należy podkreślić, że 37 ankiet nie zostało odesłanych, a 19 było niekompletnych. Ankieta zawierała 5 pytań zamkniętych wielokrotnego wyboru. Zasadniczym celem ankiety było uzyskanie odpowiedzi na pytanie o skuteczność komunikacji firm prowadzących sprzedaż w Internecie z klientami.

$\mathrm{W}$ odpowiedzi na pytanie, jakie kanały komunikacji oferuje badane przedsiębiorstwo w kontaktach z klientami, 100\% respondentów wymieniło telefon, e-mail oraz stronę WWW, 78,5\% wskazało portal społecznościowy, 59,7\% wybrało formularz na stronie internetowej, 22,2\% zaznaczyło komunikatory. Nikt z ankietowanych nie oferuje klientom bloga na portalu firmowym ani rozmowy wideo czy Skype'a. Analizę odpowiedzi na to pytanie przedstawiono na poniższym wykresie (Rysunek 1).

Badanie wykazało, że na pytanie o preferowane przez klientów kanały komunikacji respondenci, poproszeni o wskazanie co najwyżej 3 kanałów, wybrali następujące kanały: telefon, e-mail oraz stronę WWW. Nikt $\mathrm{z}$ ankietowanych nie wybrał formularza na stronie internetowej, bloga na portalu firmowym, czatu na stronie internetowej, rozmowy wideo i Skype'a, portalu społecznościowego czy też komunikatów. 


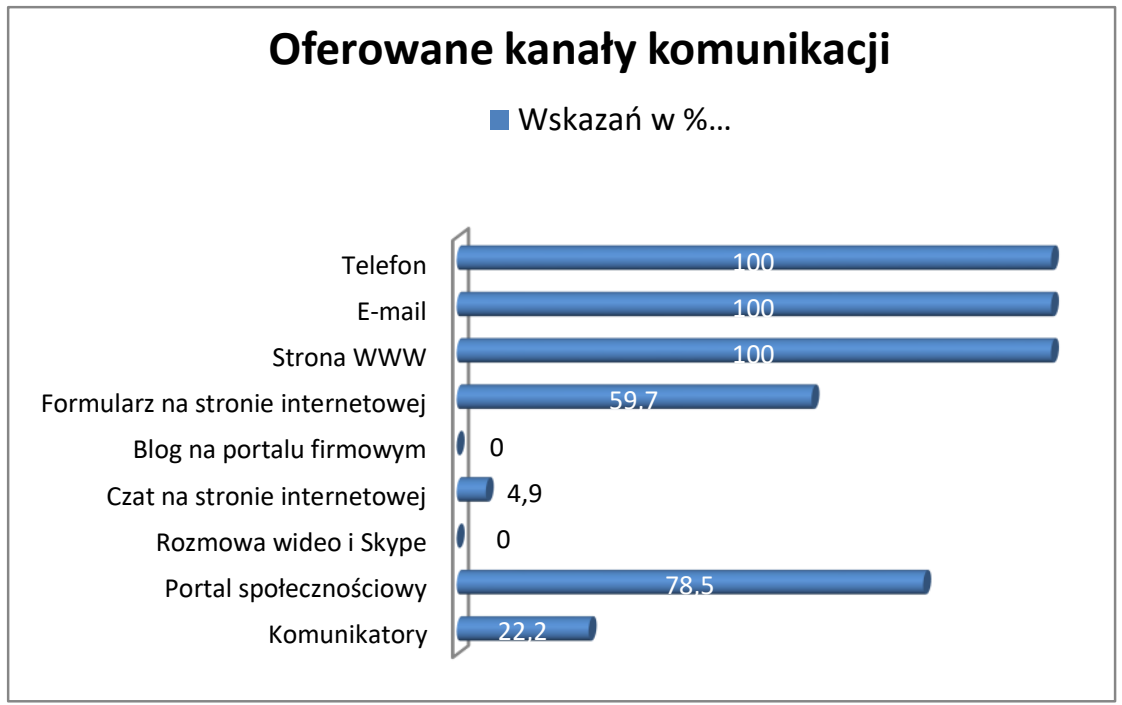

\section{Rysunek 1. Oferowane kanaly komunikacji}

Źródło: Opracowanie własne

Na pytanie, jakie kanały komunikacji badane przedsiębiorstwa planują wprowadzić do kontaktu z klientami, najwięcej respondentów wybrało czat na stronie internetowej $(45,8 \%)$, natomiast ankietowani nie planują wprowadzić bloga na portalu firmowym $(73,6 \%)$, rozmowy wideo i Skype'a $(63,9 \%)$ ani komunikatorów $(63,2 \%)$. Poniżej zaprezentowano wyniki procentowe odpowiedzi.

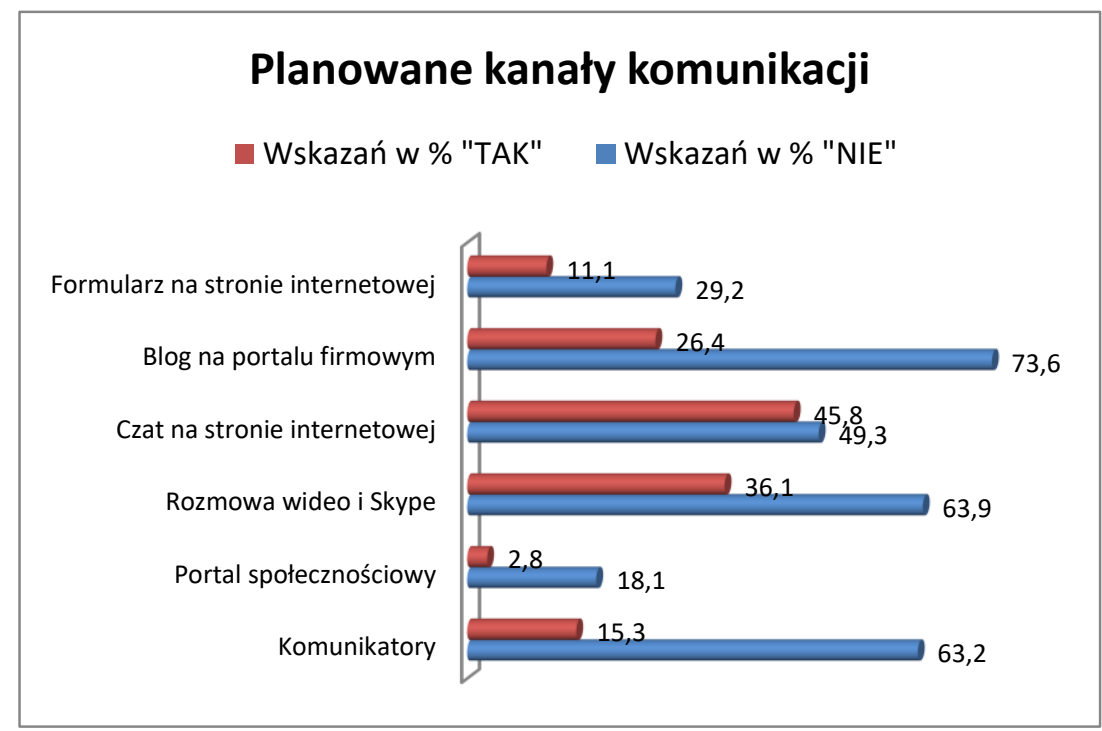

Rysunek 2. Planowane kanały komunikacji

Źródło: Opracowanie własne 
W kolejnym pytaniu respondenci mieli przyporządkować do każdego z wymienionych kanałów komunikacji odpowiedzi odnośnie ich skuteczności w skali rangowej: „bardzo skuteczny”, „,skuteczny”, „,mało skuteczny”, „,nieskuteczny”, „trudno powiedzieć”. Poniższy Rysunek 3 przedstawia zbiorcze zestawienie kanałów komunikacji wraz z ilością odpowiedzi ankietowanych wyrażoną w procentach.

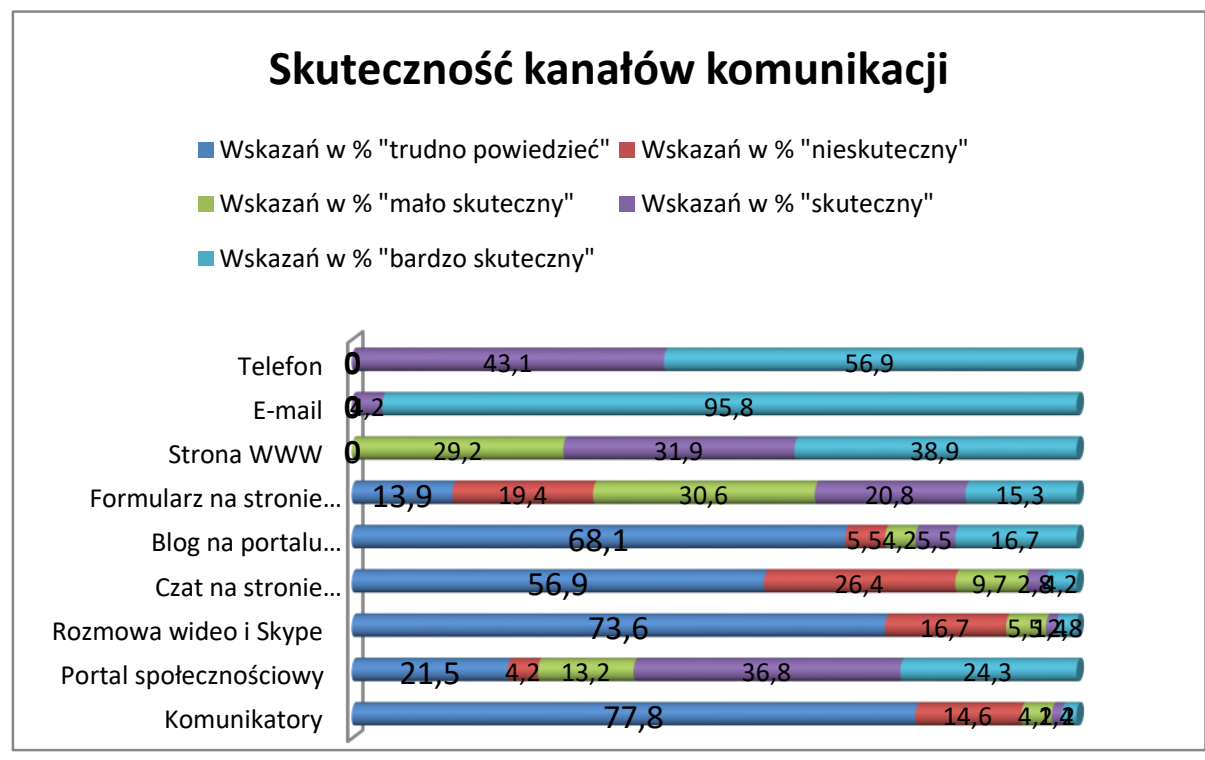

Rysunek 3. Skuteczność kanałów komunikacji

Źródło: Opracowanie własne

Zdecydowana większość wskazała e-mail $(95,8 \%)$ jako najskuteczniejszy kanał w kontakcie z klientem, a następnie telefon $(56,9 \%)$, stronę WWW $(38,9 \%)$ oraz portal społecznościowy $(24,3 \%)$. Wśród badanych kanałów komunikacji respondenci uznali, że strona WWW oraz formularz na stronie internetowej są mało skuteczne.

Celem analizy odpowiedzi uzyskanych na ostatnie pytanie było określenie najczęściej spotykanych barier w komunikacji elektronicznej.

Najwięcej odpowiedzi „nigdy” ankietowani przyporządkowali barierom społecznym $(45,8 \%)$ oraz różnicom kulturowym $(43,1 \%)$. Odpowiedz „bardzo rzadko” $48,6 \%$ respondentów przyporządkowało różnicom społecznym oraz różnicom językowym (37,5\%). Według 59,7\% ankietowanych „rzadko” pojawiają się odmienne zrozumienie komunikatu i zacieranie różnic występujących w treści komunikatu. Z kolei 33,3\% ankietowanych wskazało pominięcie części informacji jako zjawisko „częste”. Interesujący wydaje się fakt, że 11,1\% badanych firm uznało emocje za „bardzo częste”. 


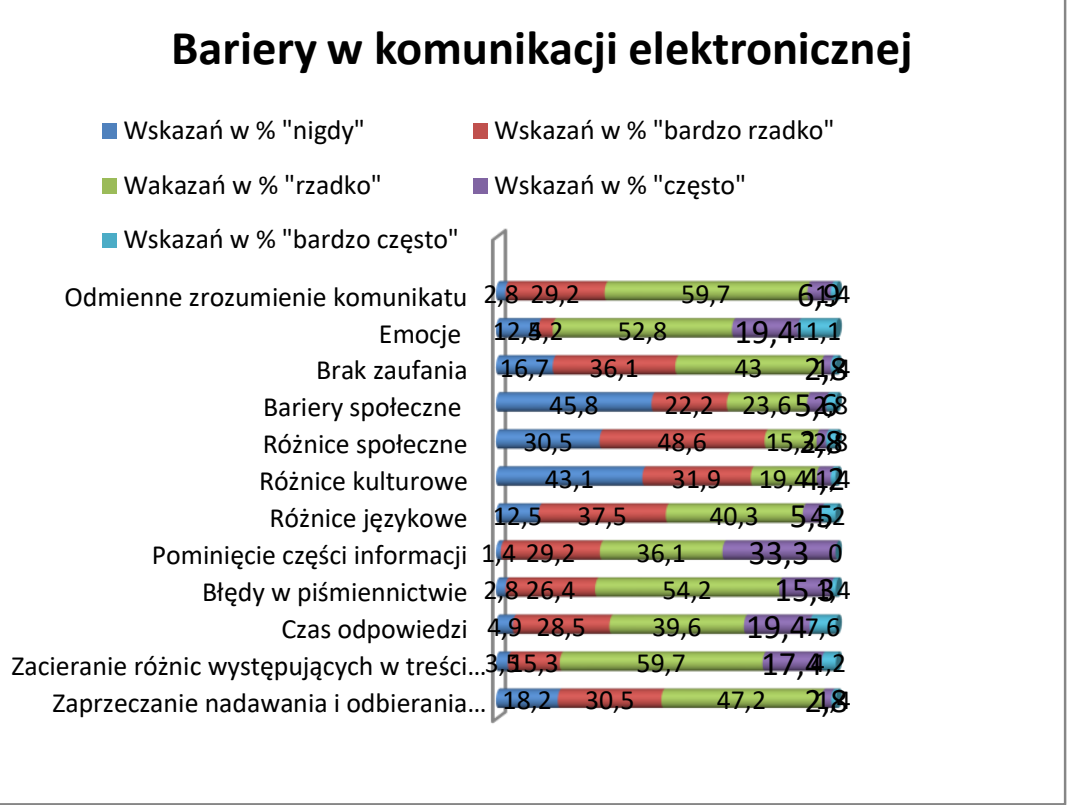

Rysunek 4. Bariery w komunikacji elektronicznej

Źródło: Opracowanie własne

\section{Podsumowanie}

Obecnie Internet stał się niezbędnym uzupełnieniem komunikacji tradycyjnej. Istnieje wiele kanałów komunikacji z klientem w e-przedsiębiorstwie. Są to kanały takie jak telefon czy e-mail, ale również bardziej nowoczesne, jak portale społecznościowe oraz Skype. Przeprowadzone badanie pokazało, że klienci z przedsiębiorstwem prowadzącym sprzedaż przez Internet najczęściej kontaktują się przez telefon, e-mail oraz stronę WWW. Respondenci uznali e-mail za najbardziej skuteczny kanał, nie mniej skuteczny okazuje się również portal społecznościowy. W przyszłości prawie połowa badanych firm planuje wprowadzić czat na stronie internetowej. Respondenci za częste bariery w komunikacji uznali pominięcie części informacji, emocje i czas odpowiedzi. Różnice kulturowe nie są przeszkodą w komunikacji. Reasumując - aby komunikacja była skuteczna, należy odpowiednio dostosować kanał komunikacji do potrzeb klientów. Możliwość skontaktowania się ze sprzedawcą poprzez urozmaicone kanały komunikacji jest niezwykle istotna, ponieważ bez wcześniejszego kontaktu ze sprzedawcą klient może zrezygnować z zakupu, dlatego też warto dbać o komunikację i minimalizować bariery komunikacyjne. 


\title{
Literatura
}

1. Amit R., Zott C. (2001), Value Creation in e-Business, "Strategic Management Journal", Vol. 22.

2. Genesys (2010), Komunikacja przez różne media - doświadczenia klientów, maj 2010, www.genesyslab.com

3. Guide de Gestion des Ressources Humaines: Communiquer efficacement avec ses employés, CSMO Caoutcouc.

4. Holstein-Beck M. (2001), Menedżer poszukiwany, Centrum Informacji Menedżera, Warszawa.

5. Hull C.E., Hung Y.T.C, Hair N., Perotti V., DeMartino R. (2007), Taking Advantage of Digital Opportunities: A Typology of Digital Entrepreneurship, "International Journal of Networking and Virtual Organisations", Vol. 4, No. 3.

6. Janas A. (2012), Perspektywy doskonalenia procesu komunikacji przedsiębiorstw z klientami i kooperantami dzięki wykorzystaniu internetowych programów konwersacyjnych, „Zeszyty Naukowe Uniwersytetu Szczecińskiego. Studia Informatica”, nr 29.

7. Januła E., Truś T. (2010), Gospodarka elektroniczna, Difin, Warszawa.

8. Jelonek D. (2014a), Ocena internetowych kanałów komunikacji z klientem w procesie wspóttworzenia innowacji, „Informatyka Ekonomiczna”, nr 1(31).

9. Jelonek D. (2014b), Zarządzanie relacjami z klientami $w$ wirtualnym otoczeniu organizacji, „Studia i Prace Kolegium Zarządzania i Finansów SGH”, nr 136.

10. Morawczyński R. (2008), Przedsiębiorczość międzynarodowa, Wydawnictwo Uniwersytetu Ekonomicznego w Krakowie, Kraków.

11. Niedźwiedziński M. (2004), Globalny handel elektroniczny, Wydawnictwo Naukowe PWN, Warszawa.

12. Nowak W. (2001), Media Planning, Marketingowy Dom Wydawniczy, Kraków.

13. Ober J. (2007), Informacja i komunikacja w zarządzaniu, Wydawnictwo Politechniki Śląskiej, Gliwice.

14. Ordysiński T. (2007), Modelowanie strategii rozwoju e-biznesu w przedsiębiorstwie, Wydawnictwo Naukowe Uniwersytetu Szczecińskiego, Szczecin.

15. ORSE (2011), Pour un meilleur usage de la messagerie électronique dans les entreprises.

\section{DETERMINANTS OF THE EFFECTIVE COMMUNICATION IN BUSINESS MODEL B2C}

\begin{abstract}
Modern commercial activities are frequently popularized on the Internet. Companies that are willing to develop their commercial operations on the domestic market and foreign markets should not only follow the new pieces of information and communication solutions but also be appropriately adapted to the specifics of their industry. Therefore, it is necessary to develop a model for effective communication both within the company and its surroundings. The major objective of this article is to identify the determinants of effective communication enterprise customers. Furthermore, the most effective communication channels are going to be presented. In order to establish the hierarchy of determinants of effective communication we conducted a survey in selected companies of the furniture industry.
\end{abstract}

Keywords: electronic communication in the company, the principles of effective communication, electronic communication tools, the effectiveness of online communication channels, communication with the customer, B2C business model 